\title{
THE ROLE OF KNOWLEDGE MASTERY AND SCIENCE PROCESS SKILLS \\ TO INCREASE THE SCIENTIFIC CREATIVITY \\ HOW DO THEY WORK?
}

\author{
Zulkarnaen $^{\bowtie 1}$, Z.A. Imam Supardi², Budi Jatmiko ${ }^{3}$ \\ ${ }^{1)}$ Universitas Mulawarman \\ ${ }^{2,3}$ Universitas Negeri Surabaya
}

\section{Article Info}

Received April 2018 Accepted May 2018

Published July 2018

Keywords:

C3PDR teaching model,

Mastery of knowledge, Science process skills, Scientific creativity

\begin{abstract}
The purpose of this research is to know how big the role of mastery of knowledge and science process skills to improve scientific creativity, using C3PDR teaching model, that is teaching model that encourage and utilize knowledge mastery, science process skill, creative thinking technique and motivation to improve student's scientific creativity. The data used are the results of pre-test and post-test of: the mastery of knowledge, scientific process skills and scientific creativity, as a result of the implementation of the model conducted in the 2015/2016 learning year. The sample of this research is 160 students of 8th grade divided into 5 classes in two schools in Samarinda city. The magnitude of the role is expressed by the coefficient of determination $\left(\mathrm{r}^{2}\right)$ and the probability value (p). Scores of the mastery of knowledge, scientific process skills and scientific creativity are grouped into 5 levels. Data were analyzed using Kendall Tau test b. The results showed: 1) mastery of knowledge plays a significant role to increase of scientific creativity by $30 \%$ indicated by the mode $\mathrm{r}^{2}>0.3$ and $\mathrm{p}$ mode $<0.0001$, in the weak category, 2) the science process skills play a significant role of $20 \%$ indicated by the mode $r^{2}>0.20$ and p mode $<0.0001$, in the weak category. Mastery of knowledge that plays a role in scientific creativity is the mastery of knowledge more broadly and in more detail. The science process skills that plays a role in scientific creativity is of determining the variables. How the role of mastery of knowledge and skills of scientific processes in enhancing scientific creativity is discussed in this article.
\end{abstract}

Corresponding author: 


\section{INTRODUCTION}

Creativity is one of the competencies that must be owned in the $21^{\text {st }}$ century, so that someone can live comfortably. Creativity is now a key educational and skills goal of the $21^{\text {st }}$ century and should be supported at school (Chan \& Yuen, 2014). C3PDR is one of the teaching model that support implementation creativity at school. C3PDR is a valid, effective and practical teaching model to enhance the scientific creativity (Zulkarnaen, Supardi \& Jatmiko, 2017). The C3PDR name is taken from the first letter of the syntax of the model, ie Creative exploration, Creative elaboration, Creative modeling, Practice scientific creativity, Discussion and Reflection. Creative theories that support the model include Investment Theory (Sternberg, 2006), DIMAI model (Agnoli \& Corazza, 2015), Scientific Creativity Structure Model (SCSM) (Hu \& Adey, 2002), and componential theory (Amabile, 1996, 2012) .

Scientific creativity consists of seven components, namely 1) fluency, flexibility and originality in the use of an object for unusual use, 2) the sensitivity to the science problem (degree of sensitivity to science problems) (3) ability to improve technical product, 4) scientific imagination, 5) ability to solve creative science problem (creative science problem solving ability), 6) ability creative experimental abilities and 7) students' ability to design creative science products abilities (Hu \& Adey, 2002). These seven components of creativity will be achieved if supported by sufficient knowledge in the field of science. According to componential theory, to be creative, one must have sufficient knowledge in his field and be supported by creative thinking skills and must be supported by high motivation. Based on these theories, the equation is obtained, three mechanisms of creativity, namely the mastery of knowledge, creative thinking skills and motivation. Mastery of knowledge becomes important in supporting creativity. How much support or contribution is the focus of the analysis of this article. Several studies have been conducted to enhance creativity through increased knowledge acquisition, including Zulkarnaen, Supardi \& Jatmiko (2017), Hu et al (2013), Zhang \& Gheibi (2015), Fotis (2010), Nami, Marsooli \& Ashouri (2014) Huang et al (2017), Chae et al. (2013), Azma \& mostafapour (2011), Poon et al (2014), Garc'ia-Garc'ia, Chulvi \& Royo (2017).

Scientific process skills are related to scientific creativity in terms of creative experimenting skills, discovering and solving scientific problems creatively and engaging in creative scientific activity. This is also supported by Amabile's compound theory (1996,
2012). Creativity will occur if supported by expertise, one of which is the procedural capability, namely the ability of how knowledge is obtained. Scientific process skills are a form of procedural capability. Several studies show that the science process skills have significant relationship to the mastery of knowledge, such as by Kaya et al. (2012), Turiman et al. (2012), Cakir \& Sarikaya (2010) and Gurses et al. (2015). The use of science process skills to enhance creativity has been used in research conducted, among others are Zulkarnaen, Supardi \& Jatmiko (2017), Chebii et al (2012) and Aktamis \& Ergin (2008).

Based on the theories and research results described above prove that the mastery of knowledge and skills of the process of science significantly contributes to creativity. The problem is how much each contributed, the mastery of the material and the skills of the science process to creativity, considering there are several other influential factors such as the ability to think creatively and motivation and how the process in the C3PDR learning model. This research answered: 1) how big the role of mastery of knowledge and process skill to increase of scientific creativity and 2) whether master of knowledge and skill of science process plays significant role to scientific creativity.

\section{METHODS}

The study was carried out in the odd semester of the 2015-2016 learning year for 10 weeks on motion topic and skeleton, joint and simple machine topic in science subjects. The sample of this research is 160 students of grade 8 that follow science subject which is divided into 5 classes, that is $8 \mathrm{G}, 8 \mathrm{E}, 8 \mathrm{~F}$ class and $8 \mathrm{C}$ and 8L class in SMPN 2 of two junior high schools in Samarinda city, East Kalimantan Province, Indonesia.

The data were collected through the test technique, using the instrument, namely 1) the knowledge assessment sheet, 2) the science skills process assessment sheets, and 3) the science creativity assessment sheets, the adaptation of the SCSM test from $\mathrm{Hu} \&$ Adey (2002). The three assessment instruments have been validated by 3 science education experts and the result, the three instruments are valid categories (Zulkarnaen, Supardi \& Jatmiko, 2017). Data collection is done before and after students are given C3PDR teaching model twice, that is for motion topic and for skeleton, joint and simple machine topics.

The data of mastering of knowledge and science process skills before and after given C3PDR learning model, in the form of interval data, converted to ordinal form with scaled $1-5$, with criterion: score 0 20 (scale 1, not good), 21-40 (scale 2, less good), 41-60 
(scale 3, good enough), 61-80 (scale 4, good) and score 81-100 (scale 5, excellent). Determination of science creativity score using SCSM model scoring techniques (Hu \& Adey, 2002). Scientific creativity scores that do not have maximum value, are converted first into a scale of $1-10$ using the $z$ distribution. The value of $z$ is determined by using the formula: $\mathrm{z}=$ (student score group average score)/standard deviation (SD). Average group and SD scores were calculated by combining pre-test and post-test scores. Determination of a large increase in the level of creativity of science, done by converting the first scale creativity data $1-10$ into the scale 1 - 5. The criteria used are: score $<1.375 \mathrm{SD}$ (not creative); $1,375 \mathrm{SD}<$ score $<-0.275 \mathrm{SD}$ (less creative); $-0.275 \mathrm{SD}<$ score $<0.825 \mathrm{SD}$ (creative enough); $0.825 \mathrm{SD} \quad<$ score $<1.925 \mathrm{SD}$ (creative); $1,925 \mathrm{SD}<$ score (very creative). The correlation coefficient ( $r$ ) and the significance of the correlation coefficient $r$ between the mastery of knowledge to the scientific creativity and the science process skills to the creativity of science, are calculated using nonparametric correlation Kendall tau $b$. The role of knowledge mastery to the creativity of science and the science process skills to the scientific creativity, determined by coefficient of determination $\mathrm{r}^{2}$. Criteria for determination coefficient levels using criteria: 0,000 - 0.199 (Very weak), $0.200-0.399$ (Weak), 0.400 0.599 (Medium), $0.600-0.799$ (Strong) and $0.80-1.0$ (Very strong).

\section{RESULTS AND DISCUSSION}

The results are presented in Table 1 and Table 2 below. 
Table 1. Coefficient of correlation and determination and probability of knowledge mastery scores on scientific creativity

\begin{tabular}{|c|c|c|c|c|c|}
\hline Value & $\begin{array}{l}\text { Grade } \\
8 \mathrm{G}\end{array}$ & $\begin{array}{l}\text { Grade } \\
8 \mathrm{E}\end{array}$ & $\begin{array}{l}\text { Grade } \\
8 \mathrm{~F}\end{array}$ & $\begin{array}{l}\text { Grade } \\
8 \mathrm{C}\end{array}$ & $\begin{array}{l}\text { Grade } \\
8 \mathrm{~L}\end{array}$ \\
\hline $\begin{array}{l}\text { The correlation coefficient }(\mathrm{r}) \text { and } \\
\text { determination }\left(\mathrm{r}^{2}\right) \text { on motion topic }\end{array}$ & $\begin{array}{l}0,56 \\
0.31\end{array}$ & $\begin{array}{l}0.62 \\
0.38\end{array}$ & $\begin{array}{l}0.42 \\
0.18\end{array}$ & $\begin{array}{l}0.54 \\
0.31\end{array}$ & $\begin{array}{l}0.47 \\
0.22\end{array}$ \\
\hline Probability (p) & $<+0.001$ & $\begin{array}{l}< \\
0.0001\end{array}$ & $\begin{array}{l}< \\
0.0001\end{array}$ & $<+0.001$ & $<+0001$ \\
\hline $\begin{array}{l}\text { The correlation coefficient }(r) \text { and determination }\left(r^{2}\right) \text { of weeks on } \\
\text { skeleton. joint and simple machine topic }\end{array}$ & $\begin{array}{l}0.47 \\
0.22\end{array}$ & $\begin{array}{l}0.57 \\
0.32\end{array}$ & $\begin{array}{l}0.66 \\
0.44\end{array}$ & $\begin{array}{l}0.64 \\
0.41\end{array}$ & $\begin{array}{l}0.42 \\
0.18\end{array}$ \\
\hline Probability (p) & $\begin{array}{l}< \\
0.0001\end{array}$ & $\begin{array}{l}< \\
0.0001\end{array}$ & $\begin{array}{l} \\
0.0001\end{array}$ & $\begin{array}{l} \\
0.0001\end{array}$ & $\begin{array}{l}< \\
0.0001\end{array}$ \\
\hline
\end{tabular}

Based on Table 1, the probability $(p)<0.0001$ topic and on skeleton, joint and simple machine topic indicates a significant role between the mastery of with mode of $30 \%$. knowledge on scientific creativity both on the motion

Table 2. Coefficient of correlation and determination and probability of science process skills score on scientific creativity

\begin{tabular}{|c|c|c|c|c|c|}
\hline Value & $\begin{array}{l}\text { Grade } \\
8 \mathrm{G}\end{array}$ & $\begin{array}{l}\text { Grade } \\
8 \mathrm{E}\end{array}$ & $\begin{array}{l}\text { Grade } \\
8 \mathrm{~F}\end{array}$ & $\begin{array}{l}\text { Grade } \\
8 \mathrm{C}\end{array}$ & $\begin{array}{l}\text { Grade } \\
8 \mathrm{~L}\end{array}$ \\
\hline The correlation coefficient $(\mathrm{r})$ and determination $\left(\mathrm{r}^{2}\right)$ on motion topic & $\begin{array}{l}0.53 \\
0.28\end{array}$ & $\begin{array}{l}0.38 \\
0.14\end{array}$ & $\begin{array}{l}0.42 \\
0.18\end{array}$ & $\begin{array}{l}0.46 \\
0.21\end{array}$ & $\begin{array}{l}0.38 \\
0.14 \\
\end{array}$ \\
\hline Probability (p) & $\begin{array}{l}< \\
0.0001\end{array}$ & $\begin{array}{l}< \\
0.0001\end{array}$ & $\begin{array}{l}< \\
0.0001\end{array}$ & $\begin{array}{l}< \\
0.0001\end{array}$ & $\begin{array}{l}< \\
0.0001\end{array}$ \\
\hline $\begin{array}{l}\text { The correlation coefficient }(r) \text { and determination }\left(r^{2}\right) \text { of weeks on } \\
\text { skeleton. joint and simple machine topic }\end{array}$ & $\begin{array}{l}0.66 \\
0.44\end{array}$ & $\begin{array}{l}0.61 \\
0.37\end{array}$ & $\begin{array}{l}0.62 \\
0.38 \\
\end{array}$ & $\begin{array}{l}0.40 \\
0.16\end{array}$ & $\begin{array}{l}0.58 \\
0.34 \\
\end{array}$ \\
\hline Probability (p) & $\begin{array}{l}< \\
0.0001\end{array}$ & $\begin{array}{l}< \\
0.0001\end{array}$ & $\begin{array}{l}< \\
0.0001\end{array}$ & $\begin{array}{l}< \\
0.0001\end{array}$ & $\begin{array}{l}< \\
0.0001\end{array}$ \\
\hline
\end{tabular}


Based on Table 2, the probability $<0.0001$ indicates a significant role between the scientific process skills of scientific creativity both on motion topic and on skeleton, joint and simple machine topic with mode of $20 \%$.

Based on Table 1, the mastery of knowledge has a significant role to the students' scientific creativity.
Knowledge is an important component of creativity. Mastery of knowledge in this research is the mastery of topics in science subjects. Table 3 describes the role of knowledge mastery of every component of scientific creativity.

Table 3. Explanation of the mastery of knowledge support to scientific creativity

Components of Scientific Creativity Explanation of Knowledge Mastery Support

Fluency, flexibility and originality use objects for scientific purposes.

Question 1: Write down as many as possible the uses of balloon for scientific activities.

Question 2: Write down as many as possible the uses of inclined plane for scientific purposes

The ability to find scientific problems creatively.

Question 1: Write down as many as many as possible, scientific questions relating to Newton's law.

Question 2: Write down as many as possible, questions about a simple machine

Ability to improve a product technically:

Question 1: Write down as much as possible what you can fix on the stopwatch to make it easier to use and more interesting. Question 2: Write down as much as possible what you can improve on a cart to be more attractive and comfortable when used.

\section{Scientific Imagination:}

Question 1: Imagine and write down as much as possible what would happen if Newton's law did not apply.

Question 2: Write down as much as possible what will happen if we do not have bones.

\footnotetext{
The ability to solve scientific problems creatively: Question 1: In Newton's second law experiment, we use a stopwatch. Write down what we can use if we do not have a stopwatch.

Question 2: Write down as many ways as possible to move an object using simple machine.
}

\footnotetext{
Ability to design an experiment, creatively:

Question 1: If you are given 2 bikes, write down as many ways as possible to test which bike is better.

Question 2: If you are given two chairs, write down as many ways as possible to test which chair is better.

The ability to design a scientific product creatively:

Question 1: Create a better and safer trampoline design picture!

Explain each part of the tool on your design!

Question 2: Create a stick design to help people who have problems

on their feet! Explain each part of the tool on your design!
}

To write down the usefulness of objects, it is necessary to master the knowledge of the object, such as its properties or in common with other objects. Various uses of the balloon can be determined by knowing the various properties of the balloon, as well as for the inclined plane.

This question relates to what students want to know more deeply about Newton's law and the simple machine, more than they already understand. To produce creative answers, ie: fluent, flexible and original, students need to know more things, such as concepts, theories, magnitudes and others, relating to Newton's law and simple machine.

The creative answer to this question requires knowledge of the object, the stopwatch and the cart, such as parts of the cart, how to keep the cart lighter despite carrying heavy items or how to use stopwatch more easily, and so on.

The creative answers to this question require mastery of knowledge of Newton's laws and bones. Students' knowledge of events that demonstrate the validity of Newton's law will make it easier for students to write down what would happen if Newton's law did not apply. The students' knowledge of bone function, will make it easier for students to write what will happen if we do not have bones.

The creative answer of question 1, requires knowledge of the basic principles of the instrument of measuring time so that by understanding the principle, students can look for alternatives to other measuring instruments that share the same basic principles. Likewise to question 2, by knowing the basic principles of simple machine, they find it easier to find other tools that work on the same basic principle.

Creative answers to this question will be easier to find if students know and understand well related to bikes and chairs. For example, students should understand the criteria of a good bike or chair. Based on these criteria, they can determine how to test it.

This creative answer will be easier to find if students know and understand well with regard to trampolines and sticks. For example, students must understand the criteria of a trampoline or a good stick. Based on these criteria, they can design a trampoline and stick that is more useful, safer and more creative. 
Note: All test questions are adapted from the scientific creativity test of $\mathrm{Hu} \&$ adey (2002).

The explanation in Table 3 shows that the mastery of knowledge plays a major role in scientific creativity. The acquisition of the desired knowledge is the mastery of a wider and more detailed knowledge.
Based on Table 2, science process skills have a significant role to the students' scientific creativity. Science process skills play a role in every component of scientific creativity, as explained in Table 4.

Table 4. Explanation of scientific process skills support to scientific creativity

\section{Components of Scientific Creativity Explanation of Science Process Skills Support}

\begin{abstract}
Fluency, flexibility and originality use objects for scientific purposes.

Question 1: Write down as many as possible the uses of balloon for scientific activities.

Question 2: Write down as many as possible the uses of inclined plane for scientific purposes

The ability to find scientific problems creatively.

Question 1: Write down as many as many as possible, scientific questions relating to Newton's law.

Question 2: Write down as many as possible, questions about a simple machine
\end{abstract}

Ability to improve a product technically:

Question 1: Write down as much as possible what you can fix on the stopwatch to make it easier to use and more interesting.

Question 2: Write down as much as possible what you can improve on a cart to be more attractive and comfortable when used.

\section{Scientific Imagination:}

Question 1: Imagine and write down as much as possible what would happen if Newton's law did not apply.

Question 2: Write down as much as possible what will happen if we do not have bones.

The ability to solve scientific problems creatively:

Question 1: In Newton's second law experiment, we use a stopwatch. Write down what we can use if we do not have a stopwatch.

Question 2: Write down as many ways as possible to move an object using a simple machine.

Ability to design an experiment, creatively:

Question 1: If you are given 2 bikes, write down as many ways as possible to test which bike is better.

Question 2: If you are given two chairs, write down as many ways as possible to test which chair is better.

The ability to design a scientific product creatively:

Question 1: Create a better and safer trampoline design picture! Explain each part of the tool on your design!

Question 2: Create a stick design to help people who have problems on their feet! Explain each part of the tool on your design!
The support of science process skills is on the determination of existing variables related to balloon and inclined plane. The ability of students to determine the variables associated with the ability to find scientific problems creatively and the ability to design experiments creatively.

The support of science process skills is in the determination of existing variables relating to Newton's law and simple machine. The ability of students to determine the variables in science process skills is very useful in compiling scientific questions, which are related to the ability to find scientific problems creatively.

The support of science process skills is on the determination of existing variables related to stopwatch and carts. The student's ability to determine helps design improvements or designs creative experiments that can be done on the product being asked.

The support of science process skills is on the preparation of hypotheses related to natural phenomena being asked. The students' ability to construct hypotheses is very useful in constructing hypotheses related to Newton's laws and bones. This ability is related to the ability to design experiments creatively.

The support of science process skills is on the ability to classify working principles on stopwatches and simple machine. Based on the classification criteria, it is easy to find other tools that can be used to solve the problem.

The support of science process skills is on the determination of existing variables related to bikes and chairs. Students' ability in determining variables helps them to design creative experiments that can be done on the product being asked.

The support of science process skills is on determining the variables that exist with respect to trampolines and sticks. The ability of students in determining variables helps design the products in question. 
Based on the explanation in Table 4, the dominant science-process skills to support scientific creativity are the skills of determining variables. The more variables it can find on a topic, the more hypotheses it can make and the more experiments it can do.

The results show that the mastery of knowledge and science process skills gives positive contribution to scientific creativity, each of $30 \%$ and $20 \%$, the rest is determined by other factors. The research that has been done shows that other factors that come from students themselves that influence creativity are creative thinking ability (Amabile, 2012) (Hu et al., 2013) (Poon et al. , 2014), motivation (Penga et al., 2013), divergent thinking skills (Huang et al, 2017) and personality (Kinga, Paul \& Sefan, 2015). Support for creativity that comes from outside the student's self is the learning environment factor (Richardson \& Mishra, 2018) (Gulliksen, 2018), teacher beliefs (Bereczki \& Kárpáti, 2018) and cultural factors (Fryer \& Bolingbroke, 2011)

This study implies that the mastery of knowledge and science process skills is not enough to educate students to be creative but needs other skills. It should be further investigated which factors are the most dominant in supporting creativity. There may be other influential factors that have not been identified yet. It implies the need for an indepth study of these factors leading to the discovery of the most dominant factor in creativity. If this is found it will facilitate teachers in improving student creativity that is a demand of 21st century competence.

\section{CONCLUSION}

Mastery of knowledge and science process skills provides a significant positive role to the students' scientific creativity even in the weak category. No matter how small the role is, it should be taken into account in the improvement of creativity because together with other factors have the potential to give a big role. Mastery of knowledge that plays a role in scientific creativity is the mastery of knowledge more broadly and in more detail. The skill of the process that plays a role in scientific creativity is the skill of determining experimental variables.

\section{ACKNOWLEDGMENT}

The authors thank to the principals of Junior High School 1 and 2 of Samarinda, East Kalimantan Province, Indonesia, and science teachers who have provided much assistance in the implementation and completion of this research

\section{REFERENCES}

Journal :

Aktamis, H., \& Ergin, Ö. (2008). The effect of scientific process skills education on students' scientific creativity, science attitudes and academic achievements. In Asia-Pacific Forum on Science Learning and Teaching, 9(1), 1-21.

azma, F., \& mostafapour, M. A. (2011). Identify knowledge management and organizational learning indicators and its relation with creativity. Procedia-Social and Behavioral Sciences, 30, 2249-2252.

García-García, C., Chulvi, V., \& Royo, M. (2017). Knowledge generation for enhancing design creativity through cocreative Virtual Learning Communities. Thinking Skills and Creativity, 24, 12-19.

Çakır, N. K., \& Sarıkaya, M. (2010). An evaluation of science process skills of the science teaching majors. Procedia-Social and Behavioral Sciences, 9, 1592-1596.

Chae, S., Seo, Y., \& Lee, K. C. (2015). Effects of task complexity on individual creativity through knowledge interaction: a comparison of temporary and permanent teams. Computers in Human Behavior, 42, 138-148.

Chan, S., Yuen, M. (2014). Creativity beliefs, creative personality and creativity-fostering practices of gifted education teachers and regular class teachers in Hong Kong. Thinking Skills and Creativity, 14, 109-118.

Chebii, R., Wachanga, S., Kiboss, J. (2012). Effects of science process skills mastery learning approach on students' acquisition of selected chemistry practical skills in school. Creative Education, 3 (8), 1291-1296.

Bereczkia, E.O., Kárpátib, A. (2018). Teachers' beliefs about creativity and its nurture: A 
systematic review of the recent research literature. Educational Research Review, 23, 2556.

Fotis, K. (2010). The interplay of creative behavior, divergent thinking and knowledge base in student's creative expression during learning activity. Creativity Research Journal, 22 (4), 387-396.

Gulliksen, M.S. (2018). Norwegian parents' perspective on environmental factors that influence creativity - An empirical grounding for future studies. International Journal of Educational Research, 88, 85-94.

Gurses, A., Gunes, K., Barin, T.B., Eroglu, Z., Cozel, F.S. (2015). Relation between preservice chemistry teachers' science literacy levels and their some scientific process skills. Procedia -Social and Behavioral Sciences, 197, 2395 - 2402.

$\mathrm{Hu}$ \&Adey. (2002). A scientific creativity test for secondary school students. International Journal of Science Education, 24 (4), 389-403.

Hu, W., Wu, B., Jia, X., Yi, X., Duan, C., Meyer, W., Kaufman, J.C. (2013). Increasing student's Scientific creativity: the "learn to think" intervention Program. Journal of Creative Behavior, 70, 3-21.

Huang, P., Peng, S.L., Chen, H.C., Tseng, L.C., Hsu, L.C. (2017). The relative influence of domain knowledge and domain-general divergent thinking on scientific creativity and mathematical creativity. Thinking Skills and Creativity, 25, 10-26.

Kaya, V.H., Bahceci, D., Altuk, Y.G. (2012). The relationship between primary school students' scientific literacy levels and scientific process skills. Social and Behavioral Sciences, 47, 495 500 .

Kinga, S., Paul, M., Sefan, S. (2015). Associations between Hexaco model of personality structure, motivational factors and self-reported creativity among architecture students. Procedia - Social and Behavioral Sciences, 187,130 - 135.

Nami, Y., Marsooli, H., Ashouri, M. (2014). The Relationship between creativity and academic Achievement. Procedia - Social and Behavioral Sciences, 114, $36-39$.

Poon, J. C. Y., Au, A. C. Y., Tong, T. M.Y., Lau, S., (2014). The feasibility of enhancement of knowledge and self-confidence in creativity: A pilot study of a three-hour SCAMPER workshop on secondary students, Thinking Skills and Creativity Journal, 14, 32-40.

Penga, S.L., Cherng, B.L., Chenc, H.C., Linc, Y. Y. (2013). A model of contextual and personal motivations in creativity: How do the classroom goal structures influence creativity via self- determination motivations? Thinking Skills and Creativity, 10, 50-67.

Richardson \& Mishra. (2018). Learning environments that support student creativity: Developing the SCALE. Thinking Skills and Creativity, 27, 45-54.

Sternberg, R. J. (2006). The nature of creativity. Creativity Research Journal, 18(1), 87-98.

Turiman, P., Omar, J., Daud, A.M., Osman, K. (2012). Fostering the $21^{\text {st }}$ century skills through scientific literacy and science process skills. Procedia - Social and Behavioral Sciences, 59,110-116.

Zhang, P., Gheibi, S. (2015). From intrinsic motivation to employee creativity: The role of knowledge integration and team psychological safety, European Scientific Journal, 11 (11).

Zulkarnaen, Supardi \& Jatmiko. (2017),.Feasibility of creative exploration, creative elaboration, creative modeling, practice scientific creativity, discussion, reflection (C3PDR) teaching model to improve students' scientific creativity of junior high school, Journal of Baltic Science Education, 16 (6), 1020-1033.

Book:

Amabile, T. M. (1996). Creativity in context: Update to the social psychology of creativity. Boulder, CO: Westview Press.

Amabile, T. M., (2012), Componential theory of creativity, Working paper, Harvard Business School.

Fryer, M., Bolingbroke, C.F. (2011). Crosscultural differences in creativity. Encyclopedia of creativity (second edition), 326-334. 